I Universidade Federal do Rio de Janeiro (UFRJ),

Departamento de Ciência da Literatura, Rio de Janeiro, RJ, Brasil

marcelodiego@letras.ufrj.br

https://orcid.org/0000-000I-8590-5009

Marcelo Diego'

\title{
O ESCRAVO VAI À ÓPERA: ÓPERA E ESCRAVIDÃO NO RIO DE JANEIRO AO REDOR DE $1850^{1}$
}

\begin{abstract}
A história da ópera no Brasil não começa nem termina com o Segundo Reinado: ela tem início em I808, por ocasião da chegada da família real portuguesa ao Rio de Janeiro, com uma pré-história que remonta à segunda metade do século XVIII; e continua até os dias atuais, atravessando todo o século XX, para chegar ao XXI. Sem embargo, foi durante o reinado de Pedro II que a ópera deixou de ser manifestação isolada, para constituir-se como sistema - daí poder-se atribuir a esse período uma importância de caráter formativo. Essa chave de leitura relativa à ópera no Brasil constrói-se por analogia à de Antonio Candido (2007), relativa à literatura no Brasil: no clássico Formação da literatura brasileira, o professor de São Paulo compreende o arco que vai do Arcadismo ao Romantismo (I750-I880, aproximadamente) como período formativo da literatura brasileira - não porque antes não houvesse produções literárias, mas porque é dentro desse arco que se constitui um sistema literário. Nas palavras do mestre,
\end{abstract}

convém principiar distinguindo manifestações literárias de literatura propriamente dita, considerada aqui um sistema de obras ligadas por denominadores comuns, que permite reconhecer as notas dominantes de uma fase. Esses denominadores são, além das características internas (língua, temas, imagens), certos elementos de natureza social e psíquica, embora literariamente organizados, que se manifestam historicamente e fazem da literatura aspecto orgânico da civilização. Dentre eles se destacam: a existência de um conjunto de produtores literários, mais ou menos conscientes do seu papel; um conjunto de receptores, formando 
os diferentes tipos de público, sem os quais a obra não vive; um mecanismo transmissor (de modo geral, uma linguagem, traduzida em estilos), que liga uns a outros. O conjunto dos três elementos dá lugar a um tipo de comunicação inter-humana, a literatura, que aparece sob esse ângulo como sistema simbólico, por meio do qual as veleidades mais profundas do indivíduo se transformam em elementos de contato entre os homens e de interpretação das diferentes esferas da realidade (Candido, 2007: 25).

O tripé sobre o qual, segundo o autor, assenta a noção de sistema - produtor, receptor e linguagem -, de matriz claramente sociológica, pode facilmente ser transposto para outras linguagens artísticas, outras produções culturais. É possível enxergar o Segundo Reinado como período de formação de um sistema operístico - uma rede consistente de produtores e receptores, que compartilham uma linguagem e um meio de circulação -, em oposição ao período anterior, quando os espetáculos líricos ainda se constituíam como manifestações isoladas.

O festim dos salões, a folia dos carnavais, o brilho dos palcos, a vida elegante pela qual a elite fluminense começara a tomar gosto com a ascensão de dom Pedro II ao trono, no início da década de I840, tiveram de ceder vez, na aurora da segunda metade do século, a uma dança macabra. À medida que se aproximava o verão de I850, alastrou-se pela cidade do Rio de Janeiro a primeira grande epidemia de febre amarela de que se tem registro. A febre começou a grassar às margens da Guanabara em setembro de I849, atingindo seu auge nos meses de janeiro e fevereiro de 1850 , para finalmente esmorecer, a partir de março. Cerca de 90.000 pessoas - mais da metade da população da Corte, que girava em torno de 160.000 habitantes - foram atingidas pela doença, que deixou ao redor de 4.000 mortos. Pouco antes de ter início o surto infeccioso, instalara-se no Teatro S. Pedro de Alcântara uma nova companhia italiana, vinda de Milão, sob a batuta do maestro Gioachino Giannini e o encanto da prima-donna Ida Edelvira. A temporada lírica, cuja première foi em 22 de agosto de I849, com I puritani, de Bellini, teve de ser interrompida em janeiro de 1850 (Cernicchiaro, I926: I87), abafada pelo galope surdo da peste. A família imperial refugiou-se em Petrópolis, em seu recém-inaugurado palácio de verão, e com ela subiram a serra todos aqueles que podiam, fossem nobres ou burgueses, burocratas ou diplomatas. Os artistas, por sua vez, foram em busca de cidades cujo público ainda tivesse forças para ir ao teatro - as principais alternativas sendo Recife e Buenos Aires (Andrade, I967: 2, 20).

Controlada a epidemia amarela, o Rio de Janeiro não tardou a retomar sua rotina, que, com o perdão do trocadilho, poderia ser descrita como febril: tinha início o período de maior estabilidade econômica e política do Império, com a popularidade de dom Pedro II em alta (Schwarcz, 2003: I 29); multiplicavam-se os bailes e saraus-concertos, alguns deles honrados com as presenças augustas de Suas Majestades. A despeito de seus hábitos reservados, dom Pedro 
II e dona Teresa Cristina iam eventualmente a bailes nos palacetes de outros membros da nobreza ou em sociedades como o Cassino Fluminense. Este funcionava na Assembleia dos Estrangeiros, no largo do Valdetaro, no Catete, que era, então, “o faubourg Saint-German do Rio de Janeiro" (Santos, I94I: 245). Em I 852, houve baile no Cassino todos os meses, de abril a novembro, tendo o imperador estado presente nos de abril, julho, setembro e outubro (Santos, I94I: 223). Ainda de acordo com Santos (I94I: 205), “o imperador 'oficializou' o Cassino Fluminense para os grandes bailes; pelo menos é o que se constata quando nos aportaram o príncipe Alfredo de Inglaterra, o grão-duque da Rússia e outros personagens". Essa percepção é semelhante à de Lilia Moritz Schwarcz (2003: I4I), para quem "se o rei não fez a corte, esta fez moda por si só. [...] Com ou sem o imperador a sociedade carioca experimentava as maravilhas da convivência social e fazia dos trópicos o último grito da moda parisiense".

Nos arredores da praça do Comércio e da rua do Ouvidor, os negócios prosperavam, com uma variedade de novos produtos tomando o lugar, na balança comercial brasileira, da mercadoria humana. Em seu capítulo de História da vida privada no Brasil, Luiz Felipe de Alencastro (2008) desmonta, peça a peça, a engrenagem econômica por meio da qual a inibição do tráfico negreiro teve como resultado o estímulo do comércio de novos produtos:

Além do mais, há uma particularidade da economia que deve ser explicada para se entender o afluxo de importados - bens de consumo e supérfluos - que transforma a vida social da corte e do Império em meados do século. [...] De fato, no ano de 1850 , os fluxos do comércio externo brasileiro conheceram uma rápida e decisiva reorientação. Considerando-se apenas os anos I84I-I850, constata-se que cerca de $335 \mathrm{mil}$ africanos haviam sido ilegalmente importados no Império, representando um valor equivalente a $28 \%$ do total das importações legais efetuadas no país na mesma época. Os pagamentos desse contrabando negreiro corriam por fora. Em letras de câmbio emitidas pelos comissários dos fazendeiros para serem sacadas, em favor dos traficantes, nas grandes casas importadoras de produtos brasileiros em Lisboa, Porto, Nova York e Londres. [...] Cessado o tráfico, ocorre um retorno das divisas obtidas nas vendas de produtos de exportação e até então reservadas para financiar a compra de africanos. O efeito na balança comercial e na balança de pagamentos do Império é imediato. Comparando-se o quinquênio de I845-1850 ao de I850-I855 (o ano fiscal corria de julho a junho), constata-se que o valor das importações do Rio de Janeiro cresce uma vez e meia. Vários fatores demonstram que houve um forte acréscimo na entrada de importados - bens de consumo semiduráveis, duráveis, supérfluos, joias etc. - destinados aos consumidores endinheirados da corte e das zonas rurais vizinhas. [...] Os artigos classificados como "não especificados" - nos quais devem estar incluídos os pianos e toda sorte de novas mercadorias de consumo - tomam proporções consideráveis na pauta de importações (Alencastro, 2008: 35-37).

Não causa espanto que um "homem das artes" engajado, como Araújo Porto Alegre, tenha caracterizado o Rio de Janeiro do Segundo Reinado como a "cidade dos pianos" (Alencastro, 2008: 48; Magaldi, 2004: 8). 
Pouco mais de um ano depois de debelada a febre amarela, a cidade sofria um novo baque: em 9 de agosto de I85I, um incêndio danificava seriamente o Teatro de S. Pedro de Alcântara, obrigando-o a fechar as portas. Não era a primeira vez que isso ocorria, nem seria a última: quando ainda atendia pelo nome de Teatro de S. João, na noite do dia 25 de março de I824, durante uma récita de gala em comemoração pelo juramento de dom Pedro I à Constituição, que acontecera na manhã daquele dia, teve início um incêndio que destruiu inteiramente o prédio, o qual foi reconstruído e reinaugurado, em 22 de janeiro de I826, como Imperial Teatro de S. Pedro de Alcântara; ele arderia mais uma vez, em 2 I de janeiro de I856, sendo rapidamente reconstruído por João Caetano, que o reinaugurou em 3 de janeiro de I857 (Silva, I938: 29). Esse edifício resistiria, com apenas pequenas reformas (incluindo a do nome: em I9I6 passa a chamar-se Teatro João Caetano), até I923, quando foi demolido e, no seu lugar, construído um novo, de estilo art déco, inaugurado em I930 - ainda de pé, embora bastante descaracterizado.

O governo tomou medidas enérgicas, para não deixar os diletantes fluminenses desprovidos de música por muito tempo, e em menos de sete meses, aos 25 de março de I852, inaugurava-se em grande estilo o Teatro Provisório, com uma récita do Macbeth, de Verdi, que tinha então sua estreia no Rio de Janeiro. Semanas depois, em 6 de abril, a bordo do vapor inglês Severn, chegavam reforços para a companhia: o baixo Mazzoletti, o tenor Bassadonna e, para o delírio das multidões, o mezzo-soprano (ou contralto) Rosine Stolz, principal responsável pelo sucesso da temporada inaugural do Teatro Provisório. Uma névoa de fascínio e mistério envolvia a prima-donna: alguns diziam que era espanhola e chamava-se Rosa Riva; outros, que era mesmo francesa, porém nascida Vittorine Noeb (Silva, I938: 46); o que todos sabiam, entretanto, é que no decênio anterior ela havia sido uma das mais destacadas cantoras da Ópera de Paris, onde criara diversas personagens, incluindo a de Leonora, na prima assoluta de A favorita, de Donizetti, em I840. Foi com esse papel que estreou na Corte fluminense, em I 2 de junho de I852. Até sua partida a bordo do vapor inglês Tay, em I5 de dezembro de I852 - pouco antes da chegada dos artistas que estrelariam a temporada seguinte, entre eles a Charton (Anne-Arsène Charton-Demeur) e a Casaloni (Annetta Casaloni) -, subiu ao palco do Provisório $3 \mathrm{I}$ vezes (Andrade, I967: 2, 33), deixando marcas de sua interpretação também na Arsace, de Semiramide, no Romeu, de Os Capuletos e os Montéquios, e na Rosina, de O barbeiro de Sevilha (Cernicchiaro, I926: I93).

Ainda em I85I, antes de o fogo lamber o velho Teatro de S. Pedro de Alcântara, Margherita Deperini, integrante da primeira Companhia Lírica Italiana, que chegou ao Rio de Janeiro, em I844, a bordo do paquete Empireo, e durante anos a fio seconda-donna desse conjunto artístico, realizou ali sua récita de despedida, de cujo programa fazia parte uma das árias da Safo, de Pacini, com a qual havia cativado o público local. Seu marido, Giuseppe, também cantor da Companhia, 
morrera naquele ano, e o contrato da cantora não fora renovado para a temporada seguinte; em face de um futuro solitário e incerto nos trópicos, a Deperini houve por bem retornar à Itália (Cernicchiaro, I926: I89). Já em I853, foi a vez da célebre Augusta Candiani despedir-se da Companhia, no palco do Teatro Provisório. Com a imagem desgastada, após um polêmico divórcio e interpretações pouco cuidadas, integrou o elenco de Semiramide como seconda-donna da Stolz; a prima-donna, em um gesto de generosidade e reconhecimento pelos serviços prestados pela Candiani, dividiu com ela os aplausos e as joias que lhe foram ofertados pelo público (Andrade, I967: I, 2 I0). Aos I 8 de agosto de I852, abriram-se as portas do novo Teatro de S. Pedro de Alcântara, administrado pelo ator e empresário João Caetano; o programa de abertura incluiu uma peça sinfônica, um drama, uma valsa e um ballet, como que a dar a nota do perfil que a casa viria a assumir, menos voltado para a arte lírica, que reinava no S. Januário e no Provisório. A propósito deste, por não mais se justificar a sua denominação primitiva, em I9 de maio de I854, com uma récita do Ernani, de Verdi, foi rebatizado como Teatro Lírico Fluminense.

Como se pode notar, a primeira metade da década de 1850 assistiu a uma intensa renovação da cena lírica, na Corte de Pedro II: em fluxo constante, artistas chegavam e partiam, uns dando lugar a outros na preferência do público, e a diva de uma temporada já não o era na temporada seguinte; teatros abriam e fechavam suas portas, passavam por reformas ambiciosas, mudavam de nome e de perfil; novos títulos eram importados e montados, de compositores novos e de novas escolas, pouco a pouco ganhando espaço aos velhos mestres, no repertório das casas de espetáculo e dos salões domésticos - "Em nenhuma outra fase de sua evolução no século XIX conheceu o Rio de Janeiro um tal entusiasmo lírico, como nos anos que vão de I853 a I858" (Andrade, I967: 2, 47). Como resultado dessa aragem do solo, a segunda metade da década de I850 viu germinar, crescer e florescer, às margens da Guanabara, um sistema operístico completo e complexo, cujos frutos acabaram por servir de alimento a outro sistema, que se formava a ele paralelo - o literário.

Parece haver, contudo, uma diferença fundamental na maneira como as duas artes se conformam como sistema, relativa à primeira perna do tripé: enquanto um sistema literário brasileiro pressupõe a existências de produtores (escritores) brasileiros, um sistema operístico brasileiro não necessariamente pressupõe a existência de produtores (compositores, libretistas, cantores) brasileiros. A "formação da ópera brasileira", em sentido estrito, é um projeto inconcluso, uma vez que, até hoje, as criações feitas no Brasil e por brasileiros não são a fonte primária que mantém ativo o meio de circulação e que sacia as demandas do público receptor de ópera no país. Por outro lado, ao se levar em conta que a ópera, como arte performática e coletiva, se torna ao longo do século XIX - e mais ainda nos séculos XX e XXI - uma linguagem globalizada, produzida por corpos artísticos internacionais, cai por terra a prerrogativa da produção estritamente nacional para a formação de um sistema local. 
A pena de José de Alencar - tanto no romance quanto na crônica e no teatro - registrou o lugar de destaque da ópera na vida social fluminense do Segundo Reinado; sobre o cenário específico da década de I850, o melhor testemunho encontra-se na produção dramatúrgica do escritor. Aos 5 de novembro de I857, na presença de Suas Majestades Imperiais, subiu ao palco do Ginásio Dramático a segunda peça teatral do autor cearense, o demônio familiar, dedicada publicamente à imperatriz. Alencar já era, então, figura que se destacava nos meios jornalístico, literário e social fluminense: filho do senador José Martiniano Pereira de Alencar, formara-se na Faculdade de Direito de São Paulo em I 850 e estreara na imprensa no ano seguinte, como colunista do Correio Mercantil; em I 855 tornara-se redator-chefe do Diário do Rio de Janeiro, por onde publicou seus dois primeiros romances, A viuvinha, em I856, e Cinco minutos, em I857; nesse mesmo ano iniciou-se como dramaturgo, com Rio de Janeiro, verso e reverso, e como tal se estabeleceu com $O$ demônio familiar, além de, como romancista, com O guarani.

A personagem a que o título faz alusão é um escravo doméstico, o moleque Pedro, que cria mil confusões entre seu amos, os irmãos Eduardo e Carlotinha, e seus respectivos namorados, Henriqueta e Alfredo. A época em que se situa a ação é registrada pela indicação, no ato I, cena 4, de que "canta a Charton" - logo, entre I854 e I856. Com a esperança de ser alforriado por seu senhor, Pedro procura, em um primeiro momento, fazer gorar o namoro de Eduardo e Henriqueta, por avaliar que, sendo a moça pobre, diminuiriam as chances de o rapaz alforriá-lo; em um segundo momento, já criado certo desentendimento entre o casal, Pedro compreende que pode conquistar as graças de seu jovem amo justamente revertendo a situação, promovendo as pazes entre Henriqueta e Eduardo. Ao fim, desfazem-se todos os mal-entendidos, os casais acertam-se, as artimanhas de Pedro são postas na conta de sua juventude e de sua condição antinatural, esdrúxula, dentro da casa de Eduardo e Carlotinha, e o escravo conquista a tão almejada liberdade.

A chamada "questão servil", que está no centro da trama de O demônio familiar, estaria igualmente na de Mãe, drama que o autor dá ao público em I 860. Em ambos os casos, a escravidão posta em cena é urbana e doméstica, daí o tema ser tratado sob o ponto de vista moral, e não econômico (Aguiar, I984: 8I-82); e se há na peça uma condenação à "nefanda instituição", é antes em função das distorções que ela gera na sociedade dos senhores, mais do que por seu impacto na vida dos escravos. Nas palavras de Décio de Almeida Prado (I974: 48),

A atitude de Alencar, liberal e paternalista, é perfeitamente evidenciada pelo tom e pelo enredo de $O$ demônio familiar, uma peça sem dúvida abolicionista, mas que vê a questão sobretudo pelo lado do senhor. A escravidão é condenada, em primeiro lugar, pelo mal que faz aos patrões, introduzindo em seus lares a mentira, a alcovitice, o mexerico, a intriga. 
O tratamento dado à questão dominou a pauta das primeiras críticas positivas e negativas - ao espetáculo, ao lado de outro ponto: a dívida de 0 demônio familiar para com Il barbiere di Siviglia, ou, mais precisamente, de Pedro para com Fígaro. O primeiro a manifestar-se, dois dias após a estreia, foi Francisco Otaviano (I857: I), nas "Páginas menores" do Correio Mercantil de 7.I I.I857, louvando as qualidades da peça e destacando seu caráter inaugural no teatro brasileiro; sobre a contradição - para não dizer aberração - nela contida, comenta apenas:

Somente há ali dois tipos, necessários para o enredo, que mostram que não há belo sem senão; que a sociedade fluminense tem no meio de suas galas algumas misérias bem feias. Um desses tipos é apenas ridículo: o outro é perverso, e o que é mais, perverso sem o saber, sem o querer, como por instinto, como por desejo de fazer o bem! (Correio Mercantil, 07.II.I857: I)

Já o segundo a debruçar-se sobre a comédia alencarina, menos de uma semana depois da sua estreia, foi Paula Brito (I857: I-2), em artigo publicado na primeira página de A Marmota de Io.I I.I857, do qual vale reproduzir dois fragmentos:

Pedro, o demônio familiar, é o Fígaro, como já dissemos, porque, mudadas as condições, mudada a cor, mudados os trajes etc., Fígaro é Pedro, e Pedro é Fígaro, tanto isto estava na mente do autor, que lá vem na comédia um pedaço da cavatina do Barbeiro, cantado por Pedro.

\section{$[\ldots]$}

Pedro, crioulo, capadócio, sabendo cantar cavatinas do Barbeiro, falando em italiano, quando levava fiori alle donne do Teatro Lírico, não sabe dizer Eu faço, eu quero, eu vou etc.; diz sempre Pedro faz, Pedro quer, Pedro vai etc., de modo que esta repetição de seu nome sempre, sempre, e sempre em tudo, dói por fim no ouvido do espectador, ao mesmo tempo que esse Pedro, que nunca se serve de pronome, nunca diz eu [...] (A Marmota, I0.II.I857: I-2).

Sem entrar na discussão da legitimidade das instituições então existentes, Paula Brito expõe o maneirismo do autor, na dicção caricata do escravo, que tem como resultado a objetificação da personagem. Com fina ironia, em vez de travar debate sobre as contradições da realidade circundante, aponta as incoerências de composição da ficção que tem diante dos olhos. De lambuja, denuncia o saque que Alencar faz a Rossini e a Beaumarchais, abalando assim um dos pilares da constituição da personalidade autoral no Romantismo, a originalidade.

Em carta aberta a Otaviano, que publica poucos dias depois, na primeira página do "Folhetim" do Diário do Rio de Janeiro de I4.I I.I857, Alencar, em vez de uma defesa aberta de $O$ demônio familiar, prefere expor a gênese da obra e o programa de sua produção teatral. Nessa espécie de manifesto - que recebeu dos comentadores a alcunha de "Como e porquê sou dramaturgo", por analogia 
com outra carta-programa, "Como e porquê sou romancista", de I873-, declara ter buscado e não ter encontrado um modelo de "alta comédia" na literatura nacional:

Dois escritores, é verdade, começaram entre nós a escrever para o teatro; mas a época em que compuseram as suas obras devia influir sobre a sua escola.

O primeiro, Pena, muito conhecido pelas suas farsas graciosas, pintava até certo ponto os costumes brasileiros; mas pintava-os sem criticar, visava antes ao efeito cômico do que ao efeito moral; as suas obras são antes uma sátira dialogada, do que uma comédia.

$[\ldots]$

Depois de Pena, veio o Sr. Dr. Macedo, que, segundo supomos, nunca se dedicou seriamente à comédia; escreveu em alguns momentos de folga duas ou três obras que foram representadas com muito aplauso.

Podemos dizer deste autor o mesmo que do primeiro, sentiu a influência do seu público; se continuasse, porém, o Sr. Dr. Macedo tem bastante talento e muito bom gosto literário, para que conseguisse a pouco e pouco corrigir a tendência popular e apresentar no nosso teatro a verdadeira comédia.

Com franqueza dizemos que sentimos ver nas obras dramáticas do Dr. Macedo uns laivos de imitação estrangeira, que lhes tira o cunho da originalidade; se ele não tivesse imaginação e poesia, seria isto desculpável; mas quando pode ser belo, sendo brasileiro, não tem justificação; é vontade de trabalhar depressa (Alencar, Diário do Rio de Janeiro, I4.II.I857: I).

Evidentemente, a compreensão que o autor tem de comédia é aristotélica e diz respeito a um drama de efeito moral, com desenlace feliz; opõe-se, assim, tanto à tragédia quanto à farsa e à sátira, sem compromisso com o elemento cômico. A despeito da reserva ao estrangeirismo que enxerga em Macedo, Alencar confessa, em seguida, ter ele mesmo estudado a escola francesa, particularmente as lições de Molière e Alexandre Dumas Filho. La question d'argent, do último, estreara em Paris meses antes, explicitando, desde o título, o núcleo duro em torno do qual, de acordo com essa escola, articulavam-se todas as tensões que poderiam servir de motivo para a criação dramática, em uma sociedade paradigmaticamente burguesa. O que Alencar acredita haver de distinto, entre a sua produção e a de Macedo, é que, assim como vinha fazendo no âmbito do romance - e vale lembrar que $O$ guarani estava sendo publicado, como folhetim, naquele mesmo I857 e naquele mesmo Diário do Rio de Janeiro -, também no teatro ele procurava casar uma forma estrangeira a um conteúdo nacional - ou nacionalista.

Flávio Aguiar (1984: 75) comenta o binômio que Alencar procurava integrar:

O "teatro nacional" deveria simultaneamente ser diferente e semelhante ao modelo europeu, francês em particular. Diferente, pois deveria ter o travo, a cor, o ambiente nacional; semelhante, pois deveria banhar o ambiente nacional dos temas, das técnicas que caracterizavam as escolas da moda. Pode-se descrever 
essa solicitação de outro modo: aquilo que se entendia por cultura teatral par excellence deveria se banhar no cenário nacional; este, por sua vez, deveria ascender à condição de se tornar, ele também, um elemento presente no concerto a "cultura". O demônio familiar, deve-se reconhecer, nada com bastante habilidade por entre as malhas dessa rede, que certamente ajudou a criar algumas monstruosidades na dramaturgia brasileira do século passado. O que Alencar fez foi juntar os problemas levantados pela "questão do dinheiro" - a comercialização dos sentimentos, a ameaça do mundo social contra a família, a riqueza como condição para o casamento -, que vinha na voga parisiense, ao travo nacional da escravidão.

Tal procedimento reproduz o que o autor levava a cabo em seus romances, para cujas incompatibilidades atenta Roberto Schwarz:

Fiel à realidade observada (brasileira) e ao bom modelo do romance (europeu), o escritor reedita, sem sabê-lo e sem resolvê-la, uma incongruência central em nossa vida pensada. Note-se que não há consequência simples a tirar desta dualidade; em país de cultura dependente, como o Brasil, a sua presença é inevitável, e o seu resultado pode ser bom ou ruim. É questão de analisar caso por caso. Literatura não é juízo, é figuração: os movimentos de uma reputada chave que não abra nada têm possivelmente grande interesse literário. Veremos que em Machado de Assis a chave será aberta pela fechadura (Schwarz, I98I: 33).

Assim, repetindo sem crítica os interesses de sua classe, Alencar manifesta um fato crucial de nossa vida - a conciliação de clientelismo e ideologia liberal -, ao mesmo tempo que lhe desconhece a natureza problemática, razão pela qual naufraga no conformismo do senso comum, de cuja falsidade as suas incoerências literárias são o sintoma. Noutras palavras, digamos que forma europeia e sociabilidade local são tomadas tais e quais, com talento e sem reelaboração. Frente a frente, no espaço estreito e lógico de um romance, contradizem-se em princípio, ao passo que a sua contradição não é levada adiante por... senso da realidade (Schwarz, I98I: 49).

A propósito, observe-se que Francisco Otaviano era o redator-chefe do Correio Mercantil, José de Alencar era o redator-chefe do Diário do Rio de Janeiro, e Paula Brito era o editor de A Marmota. Os três, portanto, ocupavam posições de liderança e chefia, nos veículos em que trabalhavam. Por isso, embora os artigos de Otaviano e Alencar ocupassem espaços dedicados a colunas de opinião, eram revestidos do peso de um editorial; no caso do artigo de Brito, esse caráter é explícito. No entanto, os três autores, como seus três periódicos, davam voz a correntes completamente distintas de pensamento e de atuação política, existentes no Brasil imperial: Alencar, branco e conservador, representava e defendia os interesses da ordem senhorial; Otaviano, branco, porém liberal, atuava de maneira diplomática (metafórica e literalmente), alinhando-se com uma tendência reformista; e Brito, negro e revolucionário, caracterizava-se por seu jornalismo militante, em prol da libertação dos escravos, e por seu ativismo social. A respeito deste, é oportuno assinalar, aqui, sua atuação pioneira e prolífica como editor musical (para uma discussão sobre seu interesse em música e um inventário das suas publicações no gênero, cf. Godói, 20I4). 
A carta-programa de Alencar lança luzes sobre alguns aspectos de sua peça, na mesma medida em que obscurece outros: o caráter precursor de $\mathrm{Ma}$ cedo e Pena é minimizado - mas e a quem se deveria a receita do quiproquó à brasileira, que dá molho a O demônio familiar, senão ao autor de $\mathrm{O}$ diletante? (Pena) -, assim como é omitida a herança de outro teatrólogo francês, Beaumarchais, entregue pelas mãos de Rossini. Cabe lembrar que, àquela altura, o autor de A moreninha (Macedo) havia escrito apenas os dramas 0 cego (I845), Cobé e O fantasma branco (I856); o juízo de Alencar, portanto, não podia levar em conta as obras-primas do autor no gênero, que são 0 primo da Califórnia (I858) e Cincinato Quebra-Louças (I873).

A ópera Il barbiere di Siviglia é citada textualmente diversas vezes, ao longo da comédia de Alencar, quando Pedro se refere a suas personagens e cantarola árias suas, desenhando a paisagem sonora sobre a qual a ação de desenrola. Além disso, na composição literária de Pedro entra uma boa dose de Fígaro, conforme observado por Paula Brito, dias após a estreia, e confirmado por Machado de Assis, quase dez anos depois, em uma avaliação global do teatro alencarino - o ensaio "O teatro de José de Alencar", que saiu em três partes, na coluna "A semana literária" do Diário do Rio de Janeiro, nos dias 6, I3 e 27 de março de i 866. Nele, "Machado de Assis, com a argúcia habitual, observou que 'o demônio da comédia, o moleque Pedro, é o Fígaro brasileiro, menos as intenções filosóficas e os vestígios políticos do outro” (Prado, I974: 29). Pedro revela traços, ainda, de outra personagem da ópera de Rossini: dom Basílio. Décio de Almeida Prado caracteriza a dinâmica de dom Basílio e Fígaro como a de uma dupla, em que o segundo desfaz o que o primeiro faz. A capacidade de intriga de Pedro residiria justamente no fato de ele reunir em si os papéis das duas personagens rossinianas (Prado, I974: 3I). Uma vez que não há

obstáculo real ao amor - oposição dos pais, desentendimentos profundos entre os namorados -, o entrecho não passa de uma série de mal-entendidos facilmente desmanchados ao final. Pedro não é Fígaro, portanto: poderia até ser considerado o anti-Fígaro, o Fígaro desastrado, por atrapalhar o amor e retardar a marcha normal dos acontecimentos (Prado, 1974: 50).

$\mathrm{Na}$ peça, é o próprio escravo que reclama para si o parentesco com o barbeiro:

Carlotinha: - Que fazes tu aí?

Pedro: - Oh! Pedro não está bom hoje, não; senhor está zangado.

Carlotinha: - Por que? Por causa de Henriqueta?

Pedro: - Sim; Pedro fez história de negro, enganou senhor. Mas hoje mesmo tudo fica direito.

Carlotinha: - Que vais tu fazer? Melhor é que esteja sossegado!

Pedro: - Oh! Pedro sabe como há de arranjar este negócio. Nhanhã não se lembra, no Teatro Lírico, uma peça que se representa, e que tem homem chamado Sr. Fígaro, que canta assim: 
Tra-la-la-la-la-la-la-la-tra!

Sono unbarbierediqualità!

Fare la barba per carità...

Carlotinha, rindo-se: - Ah! O barbeiro de Sevilha!

Pedro: - É isso mesmo. Esse barbeiro, sr. Fígaro, homem fino mesmo, faz tanta coisa que arranja casamento de sinhá Rosinha com nhonhô Lindoro. E velho doutor fica chupando no dedo, com aquele frade d. Basílio!

Carlotinha: - Que queres tu dizer com isso?

Pedro: - Pedro tem manha muita; mais que sr. Fígaro! Há de arranjar casamento de sr. moço Eduardo com sinhá Henriqueta. Nhanhã não sabe aquela ária que canta sujeito que fala groso? (Cantando) La calunnia!...

Carlotinha: - Deixa-te de prosas!

Pedro: -Prosa, não; é verso! Verso italiano que se canta!

Carlotinha, rindo: - Tu também sabes italiano?

Pedro: - Ora! Quando sr. moço era estudante e mandava levar ramo de flor a dançarina do teatro, aquela que tem perna de engonço, Pedro falava mesmo como patrício dela: 'Un fiore, signorina'.

Carlotinha: - Ah! Mano mandava flores às dançarinas! (Meio à parte) E diz que amava a Henriqueta!

Pedro: - Ora, moço pode gostar de três moças ao mesmo tempo. Esse bicho que se chama amor está nos olhos, nos ouvidos e no coração: moço gosta de mulher bonita só para ver, de mulher de teatro só para ouvir cantar, e de mulher de casamento para pensar nela todo o dia! (Ato II, cena 5. Alencar, I858: 59-60).

No fragmento, Pedro cantarola duas árias da ópera, ambas da segunda cena do primeiro ato: o "Largo al factotum", em que Fígaro apresenta à cidade seus inúmeros talentos, e "La calumnia", em que dom Basílio descreve o poder penetrante e insidioso dos rumores; ato contínuo, o moleque comete uma inconfidência, revelando a Carlotinha uma licenciosidade (ainda que totalmente autorizada pela sociedade) do irmão. O clima ameno das falas distrai o espectador da natureza violenta das ações, a conversa de salão abafa os segredos de alcova: como Fígaro, Pedro pede passagem como faz-tudo, e como dom Basílio, saca da algibeira a navalha dos boatos.

Cabe lembrar que, no cenário setecentista e provinciano em que se passa a ação de Il barbiere di Siviglia - em outras palavras, no contexto Ancien régime das relações representadas na ópera -, a posição ocupada por Fígaro, o factótum da cidade, é a de servo. Daí sua solicitude para com o conde de Almaviva e a inferioridade social em relação a dom Basílio e dom Bartolo. Por outro lado, em O demônio familiar, o projeto de Pedro, para quando em liberdade, é tornar-se um cocheiro - aquele que assume o controle sobre as bestas. Percebe-se, assim, como se arma, no imaginário de Pedro, um continuum social-existencial - nobre, assalariado, servo, escravo, animal - dentro do qual ele sabe muito bem qual é o seu lugar, em que direções pode se movimentar e até onde pode chegar. Ao incorporar larga e profundamente a ópera de Rossini a sua peça, Alencar abre uma brecha para que $O$ demônio familiar seja apreciada a contrapelo da ideologia de seu próprio autor. Decerto, a conclusão da comédia é que 
a escravidão é um inconveniente moral para os senhores, que atrasa os esforços da sociedade brasileira para civilizar-se; no entanto, suas premissas são a insubmissão dos escravos e os seus - se ainda não visões, como eles viriam a ter nas décadas seguintes (Chalhoub, I990) - vislumbres da liberdade.

Para concluir, observe-se como O demônio familiar põe a nu a relação íntima entre o universo da ópera e o universo da escravidão no Rio de Janeiro oitocentista, relação essa que se materializa em pelo menos três planos. O primeiro é o das condições de possibilidade: a mão de obra escrava era a base da economia brasileira, era ela que produzia os bens, que gerava a riqueza e que, portanto, permitia a existência de uma elite tão luxuosa quanto ociosa. No Brasil, como em outras partes da América Latina e no sul dos Estados Unidos, foi a riqueza gerada pela mão de obra escrava que financiou a importação de bens culturais da Europa, incluída aí a ópera. Por outro lado, conforme detalhado por Alencastro, a interrupção do tráfico legal de escravos, em I850, obrigou parte do comércio transatlântico a diversificar a natureza de suas mercadorias, impulsionando assim a importação para o Brasil de bens de consumo não essenciais - porém fundamentais para a percepção de uma vida de Corte e para o estabelecimento de um circuito de ópera. Assim, se em I857 a cultura da ópera permeava a sociedade fluminense a ponto de Il barbiere di Siviglia ser um referência ubíqua, partilhada por escravos e senhores, por personagens e espectadores da peça, e de árias suas serem moeda de troca corrente nas conversações, é porque havia uma cultura da escravidão que a possibilitava.

O segundo plano de relacionamento entre esses dois universos que a peça revela é o da absorção da mão de obra negra (majoritariamente escrava) pela cultura da ópera. Do mesmo modo que Pedro fazia as vezes de pajem, acompanhando Eduardo às récitas e entregando flores às prime donne em seu nome, os cronistas da época assentam que, quando as famílias senhoriais iam ao teatro, "Ninguém ficava em casa: as escravas mulheres levavam almofadas para as crianças menores, os escravos homens carregavam cadeirinhas para as maiores e até mesmo os da cozinha transportavam comidas enroladas em guardanapos, para servir durante os intervalos" (Magaldi, 2004: 39). Além disso, escravos e negros livres receberam formação musical europeia, tanto vocal quanto instrumental, por parte das próprias companhias de ópera itinerantes, das orquestras dos teatros, dos mestres das igrejas e, a partir da década de I880, na escola de música da Fazenda Imperial de Santa Cruz. Dois viajantes franceses deixaram interessantes relatos sobre suas experiências nos teatros fluminenses: Victor Jacquemont, que assistiu a uma récita de L'italiana in Algeri, de Rossini, em I828, no Teatro de São João, e registrou suas impressões em seu Voyage dans l'Inde (de I84I); e Charles Hubert Lavollée, que assistiu a uma apresentação da Norma, de Bellini, em I844, no Teatro de São Pedro de Alcântara, conforme anotou em seu Voyage en Chine, Ténériffe, Rio-Janeiro, Le Cap, Ile Bourbon, Malacca, Singapore, Manille, Macao, Canton, Port Chinois, Cochinchine, Java (de I852). 
Embora ambos os relatos sejam de décadas anteriores, a cena neles descrita conservava-se em sua maior parte a mesma, na de I850:

O público parecia aborrecer-se muito: no entanto, a sala estava cheia e é bem grande. O seu aspecto é o das salas da Itália; não há lustres, mas lampiões colocados em frente dos camarotes. As mulheres, ataviadas, os homens em traje de cerimônia, todos cobertos de condecorações, assumindo a partir dos quinze ou dezesseis anos o ar desdenhoso e enfastiado dos dandys de Regent Street. Creio que todo mundo que o Rio chama de alta sociedade tem camarote reservado na ópera. O Imperador é frequentador assíduo, porque as dançarinas e figurantes são muito do seu gosto, sem prejuízo das senhoras respeitáveis. Durante o espetáculo a praça fronteira ao teatro fica repleta de carruagens, nas quais vieram de suas chácaras os espectadores dos camarotes. Desatrelam-se as mulas, que mascam um pouco do capim empoeirado que brota aqui e ali no lugar. Os cocheiros dormem por perto ou jogam entre si e bebem. [...] A praça durante a representação parece um acampamento militar. Não há menos do que trezentos ou quatrocentos carros e mil mulas e cavalos, além de algumas centenas de servidores negros. Tudo isso é necessário ao prazer de duzentas ou trezentas famílias. Se ao menos eles se divertissem! A plateia da ópera, no Rio, pareceu-me composta por essa classe burguesa decididamente branca, formada por médicos, advogados, e pelos que ocupam posições secundárias e subalternas na administração pública. Procurei em vão pessoas de cor: elas teriam o direito de comparecer, mas provavelmente não seriam bem acolhidas (Jacquemont apud Prado, 1974: 35-36).

Há três teatros: um teatro português, onde se encenam os grandes dramas, imitados dos espanhóis; o teatro italiano, que oferece suas apresentações em uma bela sala, a de São Pedro de Alcântara (essa sala foi recentemente destruída por um incêndio; ela será sem dúvidas reconstruída). São encenadas as óperas mais conhecidas do repertório. Os cantores principais da companhia são bastante bons, mas o resto, sobretudo o coro, composto por mulatos, é penoso. São dois negrinhos, de cabelo crespo e ventre inchado, que representam os filhos da Norma. O tempo todo dá vontade de rir da mise-en-scène e aceitar essa singular cor local. O teatro italiano é o melhor frequentado; nele desfila-se com as magníficas pedrarias do império e as modas recentemente chegadas da Europa: todas as raças são admitidas, e os mestiços ricos creem vingar-se do desprezo que se tem pela sua cor por meio do luxo extravagante de suas joias, ou pelos ornamentos cintilantes sobre suas peles acobreadas. Essa mistura, aceita pelos brancos, essa igualdade de riqueza momentaneamente tolerada forma uma curioso espetáculo. Por fim, o Rio possui um teatro francês, fundado sob o patronato particular do imperador e subvencionado pelo governo; a sala é pequena, mas de bom gosto. Os numerosos franceses estabelecidos na cidade vão assistir os dramas sanguinolentos, os vaudevilles etc. (Lavollée apud Budasz, 2008: 26I).

Por fim, o terceiro plano de relacionamento entre o universo da ópera e o da escravidão é a apropriação da cultura lírica pela população negra, escrava e livre. As artes e os ofícios do espetáculo foram convertidos em um importante instrumento de profissionalização, na transição do regime de trabalho servil para o assalariado. Exemplo disso são as "vozes negras", de que fala Sérgio 
Bittencourt-Sampaio (20I2), cantoras líricas de considerável sucesso, atuantes no fim do século XIX. Sem condições de se tornar proprietários dos meios de produção - o que, no Brasil de então, significava principalmente fazendas - e com o acesso dificultado às escolas de formação nas profissões liberais - medicina, direito e engenharia -, escravos, ex-escravos e filhos de escravos encontraram na arte e na artesania não apenas um meio de vida, mas um modo de reconfigurar sua imagem e seu lugar na sociedade. Como observa Sidney Chalhoub (I990: 79), ao tomar o caminho do "escravo-artesão", os "negros teriam aos poucos se revelado como 'instrumentos de trabalho' inteligentes, mudando significativamente sua autoimagem como seres incapazes e criando tensões nas próprias percepções senhoriais a respeito do trabalho dos cativos".

Recebido em 3/I2/20I8 | Revisto em I5/3/20I9 | Aprovado em 4/4/20I9

Marcelo Diego é professor adjunto de literatura comparada na Universidade Federal do Rio de Janeiro. Doutor pela Universidade de Princeton, seus principais interesses de pesquisa são as relações intertextuais e intersemióticas entre autores brasileiros e repertórios estrangeiros, nos séculos XIX e XX. Dentre seus artigos mais recentes, destacam-se: “'Essa dona tão perversa': Carlos Drummond de Andrade, Nelson Rodrigues e as figurações da perversão na imprensa carioca da década de I940" (2019), "Memória musical no diário do conselheiro Aires” (20I8), “Napoleon's Mirrors” (20I7), “'Meu amigo e comborço': dimensões homoeróticas do Dom Casmurro de Machado de Assis" (2017) e “'Conversações do papel e para o papel': ressonâncias machadianas na obra de Carlos Drummond de Andrade" (2016). 


\section{NOTAS}

I O presente texto é uma versão, significativamente modificada, de uma seção (Ato II, cena I) da tese de doutorado Ópera flutuante: teatro lírico, literatura e sociedade no Rio de Janeiro do Segundo Reinado, realizada sob a orientação do professor Pedro Meira Monteiro e defendida na Universidade de Princeton em fevereiro de 2018.

\section{REFERÊNCIAS BIBLIOGRÁFICAS}

Aguiar, Flávio. (I984). A comédia nacional no teatro de José de Alencar. São Paulo: Ática.

Alencar, José de. (I858). O demônio familiar: comédia em quatro atos. Rio de Janeiro: Typographia de Soares \& Irmão.

Alencar, José de. (1857). Carta aberta a Francisco Otaviano. Folhetim. Diário do Rio de Janeiro. Disponível em <http://bndigital.bn.gov.br/hemeroteca-digital/>. Acesso em Io jan. 2018.

Alencastro, Luiz Felipe. (2008). Vida privada e ordem privada no Império. In: Alencastro, Luiz Felipe \& Novais, Fernando (orgs.). História da vida privada no Brasil (volume 2): Império: a corte e a modernidade nacional. São Paulo: Companhia das Letras.

Andrade, Ayres de. (1967). Francisco Manuel da Silva e seu tempo: 1808-1865. Rio de Janeiro: Tempo Brasileiro.

Bittencourt-Sampaio, Sérgio. (2012). Música: velhos temas, novas leituras. Rio de Janeiro: Mauad.

Brito, Paula. (I857: I-2). A Marmota, Rio de Janeiro. Disponível em <http://bndigital.bn.gov.br/hemeroteca-digital/>. Acesso em Io jan. 2018.

Budasz, Rogério. (2008). Teatro e música na América Portuguesa: ópera e teatro musical no Brasil (I700-I822): convenções, repertório, raça, gênero e poder. Curitiba: DeArtes/UFPR.

Candido, Antonio. (2007). Formação da literatura brasileira: momentos decisivos (I750-I880). I I ed. Rio de Janeiro: Ouro sobre Azul.

Cernicchiaro, Vincenzo. (I926). Storia della musica nel Brasile: dai tempi coloniali sino ai nostri giorni (I549-I925). Milano: Fratelli Riccioni. 
Chalhoub, Sidney. (I990). Visões da liberdade. São Paulo: Companhia das Letras.

Godói, Rodrigo Camargo de. (20I4). Um editor no Império: Francisco de Paula Britto (I809-I86I). Tese (doutorado). Instituto de Filosofia e Ciências Humanas/Universidade Estadual de Campinas.

Magaldi, Cristina. (2004). Music in imperial Rio de Janeiro: European culture in tropical millieu. Lanham, MD: Scarecrow. Otaviano, Francisco. (1857). Correio Mercantil, Rio de Janeiro, Páginas Menores. Disponível em <http://bndigital. bn.gov.br/hemeroteca-digital/>. Acesso em Io jan. 2018. Prado, Décio de Almeida. (I974). Os demônios familiares de Alencar. Revista do Instituto de Estudos Brasileiros, São Paulo, I5, p. 27-47.

Santos, Francisco Marques dos. (I94I). A sociedade fluminense em I852. Estudos Brasileiros, Rio de Janeiro, I8.

Schwarcz, Lilia Moritz. (2003). As barbas do imperador: D. Pedro II, um monarca nos trópicos. Lisboa: Assírio \& Alvim. Schwarz, Roberto. (I98I). Ao vencedor as batatas: forma literária e processo social nos inícios do romance brasileiro. 2 ed. São Paulo: Duas Cidades.

Silva, Lafayette. (1938). História do teatro brasileiro. Rio de Janeiro: Serviço Gráfico do Ministério da Educação e Saúde. 


\author{
Palavras-chave \\ Teatro lírico; \\ teatro dramático; \\ história da \\ imprensa; \\ escravidão; \\ abolicionismo.
}

Keywords

Lyrical theater;

dramatic theater;

history of the press;

slavery;

abolitionism

\section{O ESCRAVO VAI À ÓPERA: ÓPERA E ESCRAVIDÃO NO RIO DE JANEIRO AO REDOR DE 1850}

\section{Resumo}

Se, por um lado, foi a riqueza produzida pela mão de obra escrava que financiou a importação da ópera europeia para o Brasil, por outro, a proibição do tráfico negreiro foi instrumental para a instalação definitiva de um sistema de ópera no império tropical, uma vez que, como nota Luiz Felipe de Alencastro, um dos efeitos da Lei Eusébio de Queiróz foi o aumento da importação de bens de consumo supérfluos ou de luxo, que substituíram os africanos como lastro na balança comercial brasileira. A literatura e a imprensa deixaram ricos testemunhos das venturas, desventuras e contradições desse momento. A partir da peça $O$ demônio familiar (I857), de José de Alencar, bem como da polêmica travada entre Francisco Otaviano e Paula Brito a propósito dela, este artigo pretende explorar os vasos comunicantes entre os universos do teatro lírico e do regime escravista, no Rio de Janeiro ao redor de I 850.

THE SLAVE GOES TO THE OPERA: OPERA AND SLAVERY IN RIO DE JANEIRO IN AND AROUND 1850

\section{Abstract}

While the wealth produced by slave labour financed the importing of European opera to Brazil, the ban on the slave trade was instrumental to the definitive installation of an operatic system in the tropical empire. As Luiz Felipe de Alencastro highlights, one of the effects of the Eusébio de Queiróz Law was an increase in the importation of superfluous and luxury goods, replacing enslaved Africans as ballast in Brazil's trade balance. Literature and journalism left rich testimonies of the adventures, misadventures and contradictions of this period. By analysing the play $O$ demônio familiar (1857) by José de Alencar, and the controversy it generated in the press between Francisco Otaviano and Paula Brito, this paper seeks to explore the flows between the universes of lyrical theatre and slavery in Rio de Janeiro in and around 1850 . 